\title{
THE EDUCATIONALIZATION OF SCHOOL ARCHITECTURE IN SWITZERLAND BETWEEN 1840 AND 1950
}

\section{La educacionalización de la arquitectura escolar en Suiza entre 1840 y 1950}

\section{Marianne Helfenberger ${ }^{\circ}$}

Reception date: $21 / 04 / 2020 \bullet$ Aceptation date: 28/01/2021

Abstract. This paper analyses and contrasts the evolution of school architecture competitions, selected submitted projects and built schoolhouses, programmatic and professional literature, school building exhibitions and public reactions to them aiming at answering the following research question: How did architecture competitions, educational reforms and programmatic or professional literature contribute to the educationalization of the school building between 1835 and 1950 in Switzerland? The question will be approached from a perspective of educationalization, knowledge transfer and circulation between professional and political knowledge or discourses on education and practices of architecture competitions by contextualizing school building reform discourses within general school and education reform processes. The evolution of school building architecture competitions in Switzerland and the participation of a variety of actors demonstrate how the school building became a co-educator, how historical building designs are constantly naturalised to fit reform programs, and the relevance of calls for tender as source for the history of education.

Keywords: School architecture; Educationalization; Switzerland.

Resumen. El artículo analiza y contrasta la evolución de los concursos de arquitectura escolar, una selección de proyectos presentados a concurso, escuelas construidas, literatura programática y profesional, exposiciones de edificios escolares y las reacciones del público a ellos con el objetivo de responder a la siguiente pregunta de investigación: ¿cómo contribuyeron los concursos de arquitectura, las reformas educativas y la literatura programática o

a EDUDL+, Swiss Distance University, Ueberlandstrasse 12, 3900 Brig, Switzerland. marianne.helfenberger@fernuni.ch 
profesional a la educacionalización del edificio escolar entre 1835 y 1950 en Suiza? La pregunta se abordará desde una perspectiva de educacionalización, transferencia de conocimiento y circulación entre el conocimiento o los discursos profesionales y políticos sobre la educación y las prácticas de los concursos de arquitectura, contextualizando los discursos de reforma de la construcción escolar dentro de los procesos generales de reforma escolar y educativa. La evolución de los concursos de arquitectura de edificios escolares en Suiza y la participación de una variedad de actores demuestran cómo el edificio escolar se convirtió en un co-educador, cómo los diseños de edificios históricos fueron constantemente sujetos a un proceso de naturalización para adaptarlos a los programas de reforma y la relevancia de convocatorias a concurso arquitectónico como fuente para la historia de la educación.

Palabras clave: Arquitectura escolar; Educacionalización; Suiza.

\section{INTRODUCTION}

But then it was over: Hardly anyone was debating about school buildings in Switzerland. They were treated like any building project: an indoor swimming pool, a multi-purpose hall, a community centre. There was agreement: it is not the buildings that educate, but the teachers and their lessons. Why this turnaround?

This quote suggests a historical development that returns to a distant, seemingly overcome pedagogical past: a past of discipline, standardisation and teacher-centred education that neglects childhood and its needs. It also suggests that school buildings had faced a process of "de-educationalization" after a time in history that attributed school buildings educational function beyond being a container for schooling. According to Depaepe and Smeyers, ${ }^{2}$ societies tend to delegate "social responsibility to the school" trespassing the limits of traditional school curriculum. Actors in and outside the educational system try to promote their ideas and solutions regarding social problems or visions through schools. Thus, if school buildings were considered educators or at least co-educators, they must have been previously educationalized in some

\footnotetext{
1 Matthias Daum, "Das Schulhaus als Prestigebau", NZZ (Zürich), September 12, 2011: 38.

2 Marc Depaepe and Paul Smeyers, eds. Educational research: the educationalization of social problems (Dordrecht: Springer, 2008).
} 
way. Evidently, this educationalization does not deal with such socially comprehensive issues like religion, politics and technology, as problematised in Educationalization and its Complexities ${ }^{3}$, but school buildings have been deliberately related to or indirectly served other purposes than just providing space for (mass) schooling throughout history; purposes that might be more or less educational themselves. Educationalization of social phenomena has been more recently linked to modernization processes that began with the decay of the Ancien Régime and the onset of modernity in the western world, such as the development of an "educational mentality" in society that prepared the ground for public discourse about and belief in education and for the establishment and institutionalization of modern school systems. ${ }^{4}$ Beyond its political implications, once mass schooling had been successfully established and accepted by society, a variety of actors started to believe in school's potential to promote their ideals and interests by defining curriculum issues or by demanding power of definition over specific school problems. This belief still persists today despite evidence of school's failure to solve social problems. ${ }^{5}$ This essay shows that different actors successfully implemented a discourse of an educationalized school building independently from empirical evidence of its educationalizing effect.

School buildings are generally constructed to be used for decades. As "architextures", ${ }^{6}$ they can bare meaning and transmit it through forms and materials. Despite being materialised, that meaning can change throughout time. It is through such fluctuating meanings that school buildings can become (de-)educationalized. In addition, school buildings engage a large variety of interest groups, professions and, in Switzerland,

\footnotetext{
3 Rosa Bruno-Jofré, ed. Educationalization and its Complexities : Religion, Politics, and Technology (Toronto: University of Toronto Press, 2019).

4 Marc Depaepe. De pedagogisering achterna: aanzet tot een genealogie van de pedagogische mentaliteit in de voorbije 250 jaar (Leuven: Acco, 1998); Marc Depaepe and Paul Smeyers, "Educationalization as an ongoing Modernization Process", Educational Theory 58, no. 4 (2008): 379-389; David Labaree, "The Winning Ways of a Losing Strategy. Educationalizing Social Problems in the United States", Educational Theory 58, no. 4 (2008): 447-460; Daniel Tröhler, Pestalozzi and the Educationalization of the World (New York, N.Y.: Palgrave Macmillan, 2013).
}

5 Labaree, "The Winning Ways"; David Bridges, "Educationalization: on the Appropriateness of Asking Educational Institutions to Solve Social and Economic Problems", Educational Theory 58, no. 4 (2008): 461-474.

6 Henri Lefebvre, La Production de l'espace. Société et Urbanisme (Paris: Editions Anthropos, 1974). 
a multi-level political structure. Thus, (de-)educationalization of school buildings is a question of degree and can have diverse manifestations and histories with their own temporalities, changes and continuities. Official or stakeholder policies, knowledge transfer and circulation ${ }^{7}$ popularise the educationalization of school buildings. Circulation does not only take place geographically within the margins of local and international spaces, but also intersectional between professions and institutions, and thus trespasses different kinds of borders with their respective spaces of knowledge and their materializations creating new spaces of knowledge. ${ }^{8}$

This paper deals with the following research question: How did architecture competitions, educational reforms and programmatic or professional literature contribute to the educationalization of the school building between 1835 and 1950 in Switzerland? This requires a variety of sources such as calls for tender, selected submitted projects and built schoolhouses, professional association journals and programmatic literature, school building exhibitions and public reactions to them. Calls for tender have been neglected as historical source in history of education. Along with professional association journals, they can contribute to contrast degree, intensity and dynamics of educationalization of school buildings with other, especially programmatic educational sources.

In a first step, the evolution of school building architecture competitions in Switzerland will be discussed: school buildings represent cases of jurisdictional competition. This means the competition between professions for the attribution of competence and responsibility for the solution of social tasks within a system of professions. They organise themselves as a social group that has the knowledge and the capacity for abstraction to redefine given social tasks and engage in inter-professional relations to defend their professional jurisdiction. ${ }^{9}$ As cases of jurisdictional competition, both school building competitions and calls

\footnotetext{
7 Marcelo Caruso et al., Zirkulation und Transformation: Pädagogische Grenzüberschreitungen in historischer Perspektive. Beiträge zur Historischen Bildungsforschung (Köln: Böhlau-Verlag GmbH, 2013); Michel Espagne, L'histoire de l'art comme transfert culturel: l'itinéraire d'Anton Springer (Paris: Belin, 2009); Alexandre Fontaine, Aux heures suisses de l'école républicaine. Un siècle de transferts culturels et de déclinaisons pédagogiques dans l'espace franco-suisse (Paris: Demopolis, 2015).

8 David N. Livingstone, "Keeping knowledge in site", History of Education 39, no. 6 (2010): 779-785.

9 Andrew D. Abbott, The System of Professions: An Essay on the Division of Expert Labor [Reprint] (Chicago: The University of Chicago Press, 2009).
} 
for tender are indicators and pre-conditions for educationalization of the school building in educational reform and programmatic and public discourses. Second, school building reform will be contextualised within overall school and education reforms before and especially during and after the progressive education movement. Here, reform triggers and response patterns, semantic continuities and trans-professional exchange will be at the core. Third, we will discuss how the school building became a co-educator and historical building designs became naturalised to fit reform programs. Finally, the educationalization of school architecture will be discussed looking at the intersectional and trans professional relations between the participating professions. Each of these developments had its own dynamics, conjunctures and continuities within the time span of this study. Four historical moments are of special interest to these different, but entangled developments as they illustrate processes of educationalization that affect school architecture: between 1840 and 1870 as the social question became acute in Switzerland and Germany within the context of industrial upturn, around 1900 as life reform movements reacted to rapid industrialization and modernization processes, the interwar period and after World War II. Needless, to say that these historical circumstances went along with social change and socio-economic distress that triggered measures of educationalization of social problems and school critique ${ }^{10}$ and with them school building debates.

10 For the Swiss educationalization of the social question in the nineteenth and twentieth centuries see Michèle Hofmann, "Schule und die Pädagogisierung gesellschaftlicher Probleme", in Schweizer Bildungsgeschichte - Systementwicklung im 19. und 20. Jahrhundert, eds. Ingrid Brühwiler et al. (Zürich: Chronos, 2021, forth.); for the Netherlands see Nelleke Bakker and Fedor de Beer, "The dangers of schooling: the introduction of school medical inspection in the Netherlands (c.1900)", History of Education 38, no. 4 (2009): 505-524); a contemporary German Interwar source illustrates the expectation that school would solve the social question Anton H. Rose, Die Lösung der sozialen Frage durch die Schule im neuen Deutschland (Leipzig: Verlag von Wilh. Grunow, 1919); for live reform movements, industrialization and school critique see Diethart Kerbs and Jürgen Reulecke, Handbuch der deutschen Reformbewegungen 1880-1933 (Wuppertal: Hammer, 1998); Wolfgang R. Krabe, Gesellschaftsveränderung durch Lebensreform: Strukturmerkmale einer sozialreformerischen Bewegung im Deutschland der Industrialisierungsperiode (Göttingen: Vandenhoeck and Ruprecht 1974); for the aftermath of World War II and the re-education program in Italy see Cristina Allemann-Ghionda, "Dewey in Postwar-Italy: The Case of Re-Education", Studies in Philosophy and Education 19, no. 1 (2000); and for contemporary discourses in French speaking regions see Frédérique Giuliani, ed. L'école et la question sociale: les recompositions actuelles de l'action éducative. Raisons éducatives (Genève: Section des sciences de l'éducation, Université de Genève, 2018). 


\section{EVOLUTION OF SCHOOL BUILDING ARCHITECTURE COMPETITIONS (1835-1932)}

There is a need for [...] smaller class groups to allow younger children to orientate themselves, more spatially separated school areas to prevent mutual disturbance between groups, careful allocation of school time with regard to the subjects taught in school and appropriate alternation between direct teaching by the teacher and indirect teaching by assistants. ${ }^{11}$

Conrad Melchior Hirzel (1793-1843), lawyer and holder of various political offices throughout his career, diagnosed in 1829 the need to reflect on the relationship between spatial conditions and organization of schooling. For him, the school building was educational in the sense that its organization and design had to be suitable for holding school, but it was not educationalized because no other meanings were attributed to it that could serve educational purposes beyond schooling. For him, the teacher was the central educational figure, the school building was not an educator. He reacted to demands from local authorities in the Canton of Zurich who, at the beginning of the nineteenth century, the onset of modernization and expansion of mass schooling, were confronted with increasing demand for school buildings and lack of skilled master builders and architects to build them. They asked the cantonal authority, the Education Council, ${ }^{12}$ for instructions and prototype plans triggering the first competition related to school buildings in Switzerland. This is remarkable: Larger, and architectonically or from an engineering perspective challenging buildings and constructions had long been subject to professional competitions, but school buildings were mostly commissioned to specific architects or building masters without

11 Conrad Melchior Hirzel, Wünsche zur Verbesserung der Landschulen des Cantons Zürich (Zürich: Gessner, 1829), 26.

12 In Switzerland, due to its strong federalism, the owners of the schoolhouses have always been the communes, not the cantons and even less the confederation. Each canton has its own constitution and is itself more or less centralised or decentralised. The highest authority of the school system is in most cantons the so-called Education Council. Swiss communes have large autonomy in school matters. How they proceeded and to whom they delegated which decisions, was and still is diverse in Switzerland according to local traditions, proximity to rural or urban conditions, infrastructure developments, etc. Marianne Helfenberger, "Schulhausbau in Zürich von 1860 bis 1920 - zwischen Expertenherrschaft und öffentlicher Kontrolle" in Gemeinden in der Schul-Governance der Schweiz. Steuerungskultur im Umbruch, ed. Judith Hangartner and Markus Heinzer (Wiesbaden: Springer VS, 2016), 221-248. 
competition procedures or at most within the frame of invited competitions until late nineteenth century.

Together with teachers and architects, the Education Council validated a manual on how to build schoolhouses and defined the building program. The Council launched an open call for tender aiming at obtaining prototype designs of school buildings and received seven offers. It is not known whether someone was awarded or not. Plans were designed by commission members and then served together with the manual as basis for the assignment to architect Heinrich Braem to design prototypes. ${ }^{13}$ Construction manual and prototype sample were then released as official school building regulation in 1835 and $1836 .{ }^{14}$ During the nineteenth century, several cantons issued school building regulations drawing on Zurich's documents. It is evident that the Zurich documents played a role model even if the cantons adapted them to their needs and traditions. In the context of the World Exhibitions, Swiss school buildings became symbols of national quality due to their innovative heating and ventilation systems. ${ }^{15}$ The fact that most cantons did release official regulations for school building resulted in standardised expectations on hygiene, pedagogical needs, aesthetic and overall construction and aesthetic quality, enough space, solidity, light, ventilation, heating and functionality, dry construction site, absence of noise and a pleasant appearance should be all achieved. ${ }^{16}$ Nevertheless, it was not until the 1880 s that a certain degree of visible standardization developed

13 Marianne Helfenberger, Das Schulhaus als geheimer Miterzieher. Normative Debatten in der Schweiz von 1830 bis 1930, (Bern: Haupt, 2013), 70-80.

14 Erziehungsrat des Kantons Zürich, Anleitung über die Erbauung von Schulhäusern. Von dem Erziehungsrathe des Kantons Zürich gemäss § 12 des Gesetzes über die Organisation des gesammten Unterrichtswesens erlassen. Zürich, 1835; Erziehungsrat des Kantons Zürich, Musterpläne zu Schulhäusern für den Kanton Zürich 1836.

15 Marianne Helfenberger, "Climate as artefact between 1830 and 1930: A transnational construction of the Swiss school building", History of Education 47, no. 5 (2018): 237-264.

16 When the Canton of Zurich issued its regulation and prototypes for constructing schoolhouses in 1835 and 1836, copies were sent to all other cantonal authorities. Other cantons issued their own school building regulations successively after 1852, but especially after the revision of the Swiss Constitution in 1874. Many cantons had already established compulsory education before 1874 . The Federal Constitution of 1874 declared compulsory education at national level and obliged the cantons to ensure education keeping a subsidiary function in case the cantons would not take responsibility. Marianne Helfenberger and Karin Manz, "Der Auf- und Ausbau der 'modernen' Volksschule", in Schweizer Bildungsgeschichte - Systementwicklung im 19. Und 20. Jahrhundert, ed. Ingrid Brühwiler et al. (Zürich: Chronos, 2021, forth.). 
although no specific style was prescribed. School architecture had been adapted to local architecture traditions despite all regulations. ${ }^{17}$

The demand for healthy and morally impeccable surroundings and rather sober aesthetics instead of complex and loaded artistic decoration though, can point to potential educationalization of the school building. This apparently low degree of educationalization can be explained with the quality of the source: normative official documents rarely go beyond norm definitions. The experience of the social question in the mid nineteenth century is not reflected in this particular type of historical source. Towards 1900, the regulation was again revised adding hygiene norms that came in use during the second half of the nineteenth century.

After the release of Zurich's official regulations, school buildings remained relatively unaffected by the architecture profession in terms of educationalization until the Swiss Association of Engineers and Architects (SIA), founded in 1837, published its association journal in 1883. The Schweizerische Bauzeitung, ${ }^{18}$ became the main platform for publishing calls for tender and for debating architecture competitions. ${ }^{19}$ This does not mean that the school building did not become educationalized elsewhere as response e. g. to the social question between the 1840s and the 1870s (see next chapters).

The first school building competition was published in the Schweizerische Bauzeitung in $1888 .{ }^{20}$ Still, until 1900 at most one competition was published in the journal per year. The number increased after 1907, when three competitions were published. Between 1900 and 1912, 15 school buildings were announced for competition, more than three times as in the same number of years before 1900. Thus, it was not until the beginning of the twentieth century that school building competitions and calls for tender for individual school buildings began to popularise. Discussions of school building competitions were published as a written text and authored by association members or the

\footnotetext{
17 Helfenberger and Manz, "Der Auf- und Ausbau”.

18 The journal's first title was Die Eisenbahn.

19 Schweizerische Bauzeitung, Vols. 1(1883)-96(1930).

20 SIA, “Concurrenzen. Schulhaus in Riesbach”, Schweizerische Bauzeitung 11/12 (1888): 36.
} 
editorial board. In this case, school buildings were considered architecturally relevant. These circumstances generated within the SIA a polarised debate about the suitability of school buildings for architectural competitions. On one side, school buildings were not considered as technical or artistic challenges worthy of competition because they were seen as mere functional objects without aesthetic value. On the other, due to the rapidly increasing number of academically qualified architects, supply and demand of qualified architectural services went along with an international reputation of Swiss school buildings that had grown since the World Exhibitions during the last third of the nineteenth century. ${ }^{21}$ At the beginning of the twentieth century though, school buildings lost representation in Great Exhibitions; from then on they became subject of hygiene congresses, school exhibitions and school museums.

As for the calls for tender, they could be published by the editorial board in a special section of the journal or in the advertising section, which is a payed contribution mostly on behalf of the builder. Thus, calls could be used to acknowledge good competition or to condemn bad ones and to set standards for wording to distinguish professional from unprofessional competition calls. Both types of contributions to the journal testify to the defence of professional jurisdiction, which prepared the ground to redefine school buildings.

While conflicts in the competition system can affect all areas of construction, it is noticeable that the presentation of such conflicts using the example of school building competitions is by far predominant. The SIA had already established principles for competition norms and procedures. Jury members had to be explicitly named architecture professionals who have accepted the competitive conditions before publication of the competition program. The program should include detailed information about scale and construction sum. Conditions for rejecting designs and intellectual property rights were defined, advertised competitions may not be cancelled, and projects received had to be publicly exhibited during at least two weeks. ${ }^{22}$

\footnotetext{
21 Helfenberger, Das Schulhaus; Helfenberger, "Climate as artefact".

22 SIA, "Grundsätze für das Verfahren bei öffentlichen Concurrenzen", Die Eisenbahn (Schweizerische Bauzeitung) 6/7 (1877): 96.
} 
Calls for tender in the journal allowed for diverse forms of professional policies. For example, the SIA praised the commune of Monthey (Canton of Wallis, 1908) for crediting extra 500 francs to the winners of the competition in case their school building project would not be realised. ${ }^{23}$ Calls for tender also testify to the association's lobbying practices aiming at implementing its standards and principles in communes. The community office in Herisau (Canton of Appenzell Ausserrhoden) that launched a competition for a school building in 1904, accepted to appoint the competition jury, to extend the deadline and to inform those participants who already had received the competition program about the adapted conditions. ${ }^{24}$ The SIA intervened because the original announcement had violated paragraph 7 of its statutes about the jury members: According to that, the jury members should acknowledge the competition conditions and accept their nomination before publishing the call for tender. The consideration of this principle should prevent improper and exaggerated demands. ${ }^{25}$

The association actively followed policies against state authorities and institutions such as the community councils or building authorities warning colleagues from participating at competitions that did not respect the association's principles. This was the case in Lostorf (Canton of Solothurn, 1910), where neither the jury was known by the time of the call for tender nor a price was intended, and the deadline was too short to intervene in the sense of correcting the program as it was the case in Herisau. In Lostorf, community council and community assembly reserved the right to make changes and to award the final plan preparation according to their purpose. ${ }^{26}$ These are clear cases of jurisdictional competition in a complex field of activity involving experts from various disciplines, public office holders and laymen.

\footnotetext{
23 SIA, "Konkurrenzen. Schulhaus in Monthey", Schweizerische Bauzeitung 51/52 (1908): 29.

24 SIA, "Konkurrenzen. Schulhaus-Neubau in der Säge in Herisau", Schweizerische Bauzeitung 43/44 (1904): 228.

25 SIA, "Konkurrenzen. Schulhaus-Neubau", 218.

26 SIA, "Konkurrenzen. Schul- und Gemeindehaus Lostorf", Schweizerische Bauzeitung 55/56 (1910): 107.
} 


\section{School Building Competition Practices Beyond Organization of Schooling - Form, Function and Materiality}

The Schweizerische Bauzeitung also discusses problematic competition practices from a content perspective. Here again, school buildings served to illustrate bad practices in call for tender and building plan, material challenges and immaterial values of school building pointing towards educationalization. The discussions testify to the interest of the association and its members in highlighting their expertise and contrasting it with the lack of knowledge of other players in the field of school architecture and building technology. Also, within the association, a generational gap between modernists and traditionalists can be diagnosed. ${ }^{27}$

Material challenges in competitions remained constant between 1880 and 1950: fitting construction site and building program, handling distances to neighbouring buildings or dilemma between construction site and inner arrangements of buildings were recurrent. According to competitions' results, the reason for such conflicting challenges often were characteristics, desired use and location of the building plot. There were cases of irregular terrains, such as the pointed plot in Schaffhausen (1891) where a good disposition only seemed achievable by reducing the area of the playground, ${ }^{28}$ or the school building with the "dualism" of separated sections for boys and girls in Sankt Gallen (1889). ${ }^{29}$ In Schaffhausen and in Chur (1890), neighbouring buildings were also too close for ideal solutions. ${ }^{30}$ In other cases the problem was identified in the desired use of the construction site. The schoolhouse in Altstetten (1932) was to be built between larger traffic roads and the community also wished to have a free square within the plot. The jury claimed that it could not award a first price because the ideal project, a pavilion complex was not realisable under the circumstances. The jury was evidently discontent with competition program and call for tender complaining

\footnotetext{
27 Helfenberger, Das Schulhaus, 239-264.

28 SIA, "Wettbewerb für ein neues Primar-Schulhaus am Schwabenthor in Schaffhausen", Schweizerische Bauzeitung 17/18 (1891): 106-108.

29 SIA, "Wettbewerb zur Erlangung von Entwürfen für zwei Realschulgebäude in St. Gallen", Schweizerische Bauzeitung 13/14 (1889): 107.

30 SIA, "Concurrenzen. Schulhaus in Chur", Schweizerische Bauzeitung 15/16 (1890): 153; SIA, "Wettbewerb für ein neues Primar-Schulhaus am Schwabenthor".
} 
that the jury's task was to award the most suitable project for execution, not the most interesting ideas. ${ }^{31}$

In the cases dating before 1900, critique addressed architectural and educational concerns about the organization of schooling and space apparently from a mere technical perspective. As for the school building in Altstetten in 1932, there is evidence of a more educationalized case. According to the critique, the competition was apparently modern due to the high number of misunderstood pavilion projects except for the project that should have become the first prize: "But here is this human intimacy, the delicate scale appropriate to the child, a private attitude, so to speak, without monumentalism and without modernist pathos, in short, the spirit we wish for a modern school and its teaching". ${ }^{32}$ In contrast, the Neue Zürcher Zeitung, the most significant newspaper in German speaking Switzerland, emphasised the importance of the awarded school building project as urban accent. The architectural task resulting from the relationship between building program and land plot had in this discussion a positive connotation: the generous use of space and form in the exposed solutions became magnificent instead of monumental. According to the journal's editorial board, the first-awarded and recommended project considered the conditions of the task in a clear and particularly meaningful way. ${ }^{33}$ Four months later, the same newspaper reported that Altstetten's municipal council refuted the criticism at the municipal assembly. ${ }^{34}$ Once the schoolhouse was built, a report on the building from 1937 in the Schweizerische Bauzeitung confirmed that the ideal of a symbiotic relationship between the schoolhouse and the child had circulated contradicting the original critique:

Sounds of despair would silence if you just wanted to visit the schoolhouse in Altstetten on an ordinary school day and then would see how naturally and freshly house and inmates fit together

\footnotetext{
31 SIA, "Wettbewerbe. Schulhausanlage und Hallenbad in Altstetten", Schweizerische Bauzeitung 99/100 (1932): 201-202.

32 SIA, "Wettbewerbe. Schulhausanlage und Hallenbad in Altstetten", 202.

33 "Schulhaus-Wettbewerb Altstetten", NZZ (Zürich), October 3, 1932: 9.

34 “Kantone. Zürich. Altstetten”, NZZ (Zürich), February 25, 1933: 3.
} 
forming a whole that you cannot judge on the base of a façade drawing lacking ornamental forms. ${ }^{35}$

Material constraints had always been linked to practical, hygienic, pedagogical and aesthetic demands. Distance between schoolhouse and neighbouring or supplementary buildings was needed both to prevent mutual interference such as noise and reflected light that could disturb school activities and "to dodge as far as possible the aesthetically unsightly effect of the divergence of two important façades so close together". ${ }^{36}$ Thus, competitions reveal that criteria such as adequately positioned, well organised and functional floor plans and overall functionality, good light and air conditions, large and illuminated corridors, and thoughtful and artistic façades ${ }^{37}$ were always related to each other. As in every architecture competition, the main concern regarding the school building is how to combine function and form. A clear functional and architectonic relationship between school building and neighbourhood and adjacent buildings was an important criterion to award projects. In this sense, a project resulting in a harmonic architectural plan was the desired ideal. The awarded project for a school building at the Tannenrauch street in Zurich (1932) was praised because of its functional placing of showers, gym, porter's apartment and youth hostel. The last two were completely separated from the school operations and still under good supervision from the porter's apartment and all supplementary buildings were not expected to disturb classes. ${ }^{38}$ Last but not least, maximum fitting between form, function and costs also counted as positive criterion.

The fact that the competition jury for the Tannenrauch school building knew that it was the school authorities and the city council who chose between a pavilion school plan or a two or three storey main building, did not hinder the jury from admonishing the school authorities to carry out essential investigations of pedagogical, hygienic and

\footnotetext{
35 SIA, "Das Schulhaus Kappeli in Zürich-Altstetten: Architekten A. \& H. Oeschger, Zürich”, Schweizerische Bauzeitung 109/110 (1937): 227.

36 SIA, "Wettbewerb für ein neues Primar-Schulhaus am Schwabenthor"; SIA, "Wettbewerb für ein Primarschulhaus an der Tannenrauchstrasse in Zürich", Schweizerische Bauzeitung 99/100 (1932): 312-315.

37 SIA, "Concurrenzen. Schulhaus in Chur"; SIA, "Konkurrenzen. Schul- und Gemeindehaus Lostorf".

38 SIA, "Wettbewerb für ein Primarschulhaus an der Tannenrauchstrasse".
} 
financial nature. This caveat was suggestive as it identified pavilion school complexes with modernity, even though several pavilion projects apparently misunderstood the concept. Without any explanation, the jury is convinced that "it seems certain that for the time being this is advisable for primary school, for which the advantages of low-rise construction are clearer than in secondary schools". ${ }^{39}$

The first school building designed as pavilions in Switzerland dates from 1907, it was built in Tavannes (Jura), a francophone commune. However, the idea of the pavilion system had been tested in Zurich in 1904. It was then initially called "school barracks" and not school pavilions. Both terms were used as synonyms until the Swiss Association for School Hygiene (Schweizerische Gesellschaft für Schulgesundheitspflege) proposed to refrain from using the term "school barracks" to avoid associations with unstable wooden huts. The Swiss Association for School Hygiene wanted to promote the pavilion system for health and hygiene reasons. Historical models were pavilion hospitals constructed during the American Independence War and later in Paris and Berlin. Possibly provisional and reusable buildings, the barracks or pavilions became the schoolhouse of the future. But architects in the 1930s presented it as a modernist architectural innovation to which school authorities should respond positively in the name of the child. ${ }^{40}$ These cases demonstrate how reform architecture discourses adopt patterns of educational reform and transform the original meaning of an architectural form, here the pavilion design. The reception is selective and new tradition lines are deliberately created. ${ }^{41}$ Instead of recalling the medical-architectural origins of the pavilion schools, reform architects referred to Pestalozzi or other pedagogical authorities to pedagogically legitimise their position. ${ }^{42}$

Despite the fact that modern architecture claimed authorship of the motto 'form follows function', historical evidence demonstrates that this has been the ideal ever since. Between 1880s and 1950, school building

\footnotetext{
39 SIA, "Wettbewerbe. Schulhausanlage und Hallenbad in Altstetten", 201.

40 Helfenberger, Das Schulhaus, 155-164.

${ }^{41}$ Jürgen Oelkers, "Reformpädagogik: Aktualität und Historie", in Reformpädagogik kontrovers, ed. Wilfried Böhm and Jürgen Oelkers. (Würzburg: Ergon Verlag, 1999), 37.

42 Alfred Roth, The new school = Das neue Schulhaus = La nouvelle école (Zürich: Girsberger, 1950), 28.
} 
projects having an "artistic and original façade developed from the floor plans" ${ }^{43}$ or having simple architectural forms according to the building's function (Zürich 1905) ${ }^{44}$ were normally handled preferentially; and if not, critique did not remain silent.

\section{SCHOOL BUILDING REFORM - SOCIAL TRIGGERS AND RESPONSE PATTERNS}

School building reform does not follow own rules. It is closely linked to school and educational reforms and follows the same genetic and discursive patterns and historical contingencies. School reform actors react to social change and are rarely exclusively motivated by pedagogic and educational ideals. Thus, school reforms result from an interaction between individual and collective intentions and non-targeted social change. Triggered by diagnosis of danger, inequalities and other social disorders, and apparent predominance of materialism or utilitarianism vs. moral and immaterial values, school reformers envisage reforms beyond the limits of the school institution aiming at changing society as a whole towards an alleged lost paradise or a future ideal. Depending on the degree of collective perception of the necessity to reform, the need for legitimatizing reform programs is higher or lower. ${ }^{45}$ In this sense, "education [has] always been New Education", a "continuum, constantly challenged the 'old' through the 'new education' without any clearly discernible demarcation of 'before' and 'after'”. ${ }^{46}$ Apart from general legitimation strategies such as constructing traditions recalling on and idealising historical educational authorities ${ }^{47}$ or, in case of institutional

\footnotetext{
43 SIA, "Concurrenzen. Schulhaus in Chur".

44 SIA, "Konkurrenzen. Wettbewerb für ein Sekundarschulhaus mit Turnhalle an der Ecke der Riedtl- und der Röslistrasse in Zürich", Schweizerische Bauzeitung 45/46 (1905): 144.

45 For new theoretical approaches on school reform in general see Flavian Imlig, Lukas Lehmann and Karin Manz, eds. Schule und Reform: Veränderungsabsichten, Wandel und Folgeprobleme. Educational Governance (Wiesbaden: Springer Vieweg, 2018).

46 Jürgen Oelkers, "Reformpädagogik vor der Reformpädagogik", Paedagogica Historica 42, no. 1-2 (2006): 15-48, abstract.

47 Fritz Osterwalder, Pestalozzi - ein pädagogischer Kult : Pestalozzis Wirkungsgeschichte in der Herausbildung der modernen Pädagogik (Weinheim, Basel: Beltz, 1996).
} 
and structural reforms, on foreign practices ${ }^{48}$ to add credibility to reform projects, specific patterns of discourse and a series of leitmotifs complemented the semantic and rhetoric repertoire of educational reform since the progressive education movement: child centred and individualising approaches, self-activity, claims for a comprehensive approach to include and highlight the educational value of manual work, freedom for self-development, object lessons and nature experience. Most relevant for school building reform discourses is the imaginary of the child both as free from original sin and society's potential redeemer and as naturally free, curious, receptive and self-determined. ${ }^{49}$ Last but not least, progressive educators tend to build up their reform arguments upon the remembrance of their own educational experience as a child. ${ }^{50}$

School building reform architects, as we will see, adopted these patterns to legitimise their aesthetic modernisation of school architecture which was embedded in general contemporary architecture trends and values. By doing so, they educationalized the school building and they acted as pedagogues in favour of an architectural creed that they wished to popularise in society to defend and expand their professional jurisdiction.

Nineteenth century societies experienced an unprecedent school building boom due to the implementation of compulsory schooling and other modernizing processes within and outside the school system. School itself underwent profound transformations and differentiations in a "series of successful problem solutions" 51 delivering endless prototypes for local school buildings. Under these circumstances, school buildings became symbols of modernity and progress. ${ }^{52}$ At a teacher

\footnotetext{
48 Phillip Gonon, Das internationale Argument in der Bildungsreform : Die Rolle internationaler Bezüge in den bildungspolitischen Debatten zur Schweizerischen Berufsbildung und zur englischen Reform der Sekundarstufe II. Explorationen (Bern: Peter Lang, 1998); Bernd Zymek, Das Ausland als Argument in der pädagogischen Reformdiskussion: Schulpolitische Selbstrechtfertigung, Auslandspropaganda, internationale Verständigung und Ansätze zu einer Vergleichenden Erziehungswissenschaft in der Internationalen Berichterstattung. Schriftenreihe (Kastellaun: Aloys Henn, 1975).

49 Jürgen Oelkers, Reformpädagogik: Eine kritische Dogmengeschichte (Weinheim, etc.: Juventa-Verlag, 1996); Fritz Osterwalder, "Das gute Kind - pädagogische Modernität und ihr theologisches Erbe", in Gut/Böse-ein Januskopf? ed. Eva Marsal and Regina Speck (Bern, Frankfurt a.M.: Lang, 2008), 19-41.

${ }_{50}$ Klaudia Schultheis, "Reformpädagogik - eine Pädagogik vom Erwachsenen aus?", in Reformpädagogik konstrovers, ed. Winfried Böhm and Jürgen Oelkers (Würzburg: Ergon, 1995), 89-104.

51 Oelkers, "Reformpädagogik vor der Reformpädagogik".

52 Helfenberger, Das Schulhaus, 135-139.
} 
conference meeting, teacher Johann Georg Schoch took his audience back in time into a school building from the early nineteenth century where he himself could have had attended school. ${ }^{53}$ The building had been in bad shape and correlated with his idea of old-fashioned education: the only objects decorating the walls were punishment instruments. Fifty years later, he was convinced that pedagogical progress had taken place and that it was visible in new school buildings. This example illustrates how nineteenth century teachers held distance from an allegedly backward past and celebrated their present as success giving opportunity to optimistic attitude towards the future. Thus, school buildings became the material counterpart of education as a source of individual and social wealth and prosperity. School would take the lead and be an example to follow and to identify with.

The mid nineteenth century was faced with the social consequences of industrialization. Demographic movements towards the cities furthered high population density leading to the inevitable perception of social inequalities and to unhealthy living conditions. This contrasted with the civil idea of equality leading to a shift in perception and meaning of poverty and individual responsibility. Poverty could not be considered self-inflicted or God given anymore, the social structure could be recognised as cause and appealed to social responsibility.

School and society underwent processes of medicalization and educationalization. Under medicalization ${ }^{54}$ we understand the process by which social phenomena become medical facts, problems that can be treated medically leading to decreased social tolerance towards them; it addresses the social construction of health and illness. ${ }^{55}$ Thus, it not only

53 G. Schoch, "Ein Wort zur Eröffnung der appenzellischen Lehrer-Conferenz, gesprochen von ihrem diessjährigen Präsidenten, G. Schoch in Trogen, zu Teufen den 9. Juni 1856”, Pädagogische Montasblätter für die Schweiz 1 (1856): 262.

54 Claudia Peter and Carolin Neubert, "Medikalisierung Sozialer Prozesse”, in Soziologie von Gesundheit und Krankheit, ed. Matthias Richter and Klaus Hurrelmann (Wiesbaden: Springer Fachmedien Wiesbaden, 2016), 273-285; Conrad Peter, The medicalization of society. On the transformation of human conditions into treatable disorders (Baltimore: John Hopkins University Press, 2007); Irving K. Zola, "Medicine as an institution of social control", in The sociology of health and illness. Critical perspectives, ed. Peter Conrad (New York: Worth, 1972), 404-414.

55 See for example Michel Foucault, Die Geburt der Klinik: eine Archäologie des ärztlichen Blicks (Frankfurt am Main: Fischer Taschenbuch, 2016); Francisca Loetz, Vom Kranken zum Patienten: "Medikalisierung" und medizinische Vergesellschaftung am Beispiel Badens, 1750-1850 (Stuttgart: 1993). 
functions as instrument of social control, but goes beyond the appropriation of new problems and social tasks by the medical profession in the sense of defending its professional jurisdiction. ${ }^{56}$

The hygienic school building discourse of the mid nineteenth century was characterised by the emphasis on danger and health threat to which the bodies of school children were really or allegedly exposed within the schoolhouse and its surroundings. ${ }^{57}$ Complaints concerned not only the common hygienic challenges and construction deficits such as narrow and steep stairs which were identified as potentially dangerous. Also, medical issues entered the school building discourse, for example myopia.

Myopia is a medical fact that can occur at any age. A predisposition to it can be inherited, thus, it is a natural phenomenon despite the fact that environmental conditions can favour it. It's actual spread in the population became visible only through mass schooling. This visibility was socially induced and prepared the ground for a reinterpretation of myopia as a field of social responsibility on one side and as part of the professional jurisdiction of the medical profession on the other. Medical professionals engaged in large scaled empirical diagnostic tests to demonstrate school's unhealthy conditions and to popularise this new knowledge in society. ${ }^{58}$ With Latour, ${ }^{59}$ it can be stated that myopia, as a natural medical fact, intervened as an actor in society triggering social networks competing for power and control of the population. In consequence, it could become educationalized by delegating to school and school buildings a central role to prevent the development of child myopia. ${ }^{60}$

56 Michèle Hofmann, Gesundheitswissen in der Schule. Schulhygiene in der deutschsprachigen Schweiz im 19. und 20. Jahrhundert (Bielefeld: transcript, 2016).

57 Hofmann, Gesundheitswissen in der Schule.

58 Michèle Hofmann, "Ein schwacher Geist in einem schwachen Körper? Popularisierung medizinischen Wissens über geistige Schwäche im ausgehenden 19. und beginnenden 20. Jahrhundert in der Schweiz", Spurensuche. Zeitschrift für Geschichte der Erwachsenenbildung und Wissenschaftspopularisierung, 27 (Die Bildung des Körpers - Medizin, Gesundheit und Bewegung in der Volks- und Erwachsenenbildung des 19. und 20. Jahrhunderts) (2018): 4-13.

59 Bruno Latour, The Pasteurization of France (Cambridge, Mass.: Harvard University Press, 1993).

${ }^{60}$ Hofmann. "Schule und die Pädagogisierung gesellschaftlicher Probleme". 
Against this background, the school building could be criticised and reassessed. German doctors engaged in school building critique, among them Georg Varrentrapp ${ }^{61}$ who is particularly relevant for the Swiss case because he highlighted the modernity of Zurich's regulation and Swiss school buildings in general: In Switzerland, school buildings had become distinguished buildings after the first third of the nineteenth century. ${ }^{62}$ Varrentrapp did not need to radically break with school building tradition because none had been developed in German cities in the sense that, according to him, schools did not look like schools but rather than any other representative building. Thus, school building tradition had to be developed by designing a specific building typology so that school buildings could be recognised as such. Varrentrapp referred to Zurich's regulation from 1861, a minimally revised version of the original one from 1835. In terms of reform processes, it cannot be stated that the revision represented a radical break with the past and the tradition of the prototypes from the 1830s. Varrentrapp's school building critique reacted to city school buildings with "impressive façades" that displayed diverse architecture styles without taking into account light and air conditions needed in schools.

For Varrentrapp, much attention had been given to artistically elaborated façades and the child's mental and moral development, but none to the child's physical development. Thus, the school building did not reflect on the outside what would be its function inside. Adapting the façades to the function of the building would also transmit to children and citizens a more correct idea of schooling and also add to its acceptance. The schoolhouse should be perceived as such, as educational site of the child, by the child and the population in general. Even in places where school

\footnotetext{
${ }_{61}$ Georg Varentrapp (1809-1886) worked not only as physician, he also designed construction plans for the hospital in Frankfurt. His engagement with social issues began as co-founder of a clinic for the poor in 1834. He was also active in jails, schools, public hygiene and public health, especially aiming at improving the construction of school buildings, fabrics, prisons, hospitals and urban sewer systems. Roediger, Emil. "Varrentrapp, Georg”, in Allgemeine Deutsche Biographie 39 [1895], 500502 [online version]. http://www.deutsche-biographie.de/ sfz83539.html, 500-502 (retrieved January 26, 2021).

62 Helfenberger. Das Schulhaus; Elisabeth Schneeberger, Schulhäuser für Stadt und Land. Der Volksschulhausbau im Kanton Bern am Ende des 19. Jahrhunderts (Bern: Historischer Verlag des Kantons Bern, 2005); This Oberhänsli, Vom "Eselstall" zum Pavillonschulhaus: Volksschulhausbauten anhand ausgewählter Luzerner Beispiele zwischen 1850 und 1950 (Luzern: Kommissionsverlag Raeber Bücher AG, 1996).
} 
had been legally declared compulsory, it had not yet been completely implemented or people still had to be convinced, ${ }^{63}$ so that placing the schoolhouse as an urban accent correlated with this idea of education and the child. And Varrentrapp considered that Switzerland had already accomplished these requirements. ${ }^{64}$

From this perspective, school building critique became possible against school architecture that supposedly did not respect these societal demands: façades could now be seen as undeveloped from a pedagogical and medical point of view independently from their architectural value. Architects who favoured impressive and mighty façades highlighting architectural styles would not represent schooling nor distinguish school buildings from other buildings. ${ }^{65}$ The kind of façades criticised by Varrentrapp was not common in rural areas in nineteenth century Europe. In this sense, school building reform was an urban phenomenon before progressive education diagnosed an alienating effect as characteristic of large cities. ${ }^{66}$ Knowledge transfer and circulation at the World Exhibitions in the last third of the nineteenth century reinforced the centripetal movement of school building reforms. ${ }^{67}$

Life reformers at the beginning of the twentieth century proclaimed inner-worldly orientation and models of societal change through arts, nurture, return to nature and local values aiming at creating a better society and protecting it against the consequences of growing urbanization and modernization that were perceived as dangerous economical threat due to foreign market influences. ${ }^{68}$ Within the context of the

\footnotetext{
63 Rudolf Braun, "Arbeits- und Lebensverhältnisse des Fabrikwesens als soziales Problem" in Sozialer und kultureller Wandel in einem ländlichen Industriegebiet im 19. und 20. Jahrhundert, ed. Rudolf Braun. (Zürich: Chronos, 1999), 109-185.

${ }^{64}$ Helfenberger, Das Schulhaus.

65 Georg Varrentrapp, Der heutige Stand der hygienischen Forderungen an Schulbauten (Braunschweig, 1869), 5.

66 Oelkers, "Reformpädagogik: Aktualität und Historie".

67 Helfenberger, “Climate as artefact”, 22-24.

68 Stefan Rindlisbacher, Die Schweizer Lebensreformbewegung: Anleitungen für ein "besseres Leben", in Lebe besser! : auf der Suche nach dem idealen Leben, ed. Eva Locher (Bern: Eigenart, 2020), 17-29; Peter Michalzik, 1900: Vegetarier, Künstler und Visionäre suchen nach dem neuen Paradies (Köln: DuMont, 2018); Marcel Schmid, ed. Die Literatur der Lebensreform: Kulturkritik und Aufbruchstimmung um 1900 ( Bielefeld, Germany: transcript, 2016).
} 
heritage protection movement, Swiss (national, regional and local) identity was seen as endangered by foreign influences that would alienate the people from their local traditions and values. Action plans to protect the cultural heritage also included the school building.

As it was the case with the historical period of progressive education around 1900, school building reformers, both architects and educators, also "increasingly crystallised around certain themes and motives" ${ }^{69}$ proposing alternatives to school buildings built by state architects and adopting patterns of reform discourses to school architecture. Thus, school building reforms are urban phenomena, they radically break with the past, especially with the nineteenth century, and their actors often recur to autobiographical childhood experiences as a lost paradise.

At the beginning of the twentieth century, educational and school building reformers adopted a specific relationship to past and present. By recalling a lost paradise, they created proximity to childhood and distance to a harmful present in face of alleged decay and alienation from which children have to be protected by building schoolhouses that resemble their homes. Hermann Roethlisberger, Swiss pedagogue and activist of the Swiss Heritage Protection Association, ${ }^{70}$ recalled his childhood contrasting the schoolhouse with the parsonage to justify his adult aesthetic needs and engagement: the schoolhouse was boring and thus did not mark his soul while the parsonage was aesthetically appealing and impressed him. ${ }^{71}$

Evoking childhood's and youth's intrinsic value results in conceiving the schoolhouse as protected material space, as materialization of youth as pedagogical moratorium. ${ }^{72}$ Through the materiality of the schoolhouse,

\footnotetext{
69 Oelkers, "Reformpädagogik: Aktualität und Historie".

70 The Swiss Heritage Protection Association was founded in 1905 to protect Switzerland's material and immaterial cultural heritage by publicity, political lobbying and pedagogical activities.

71 Hermann Röthlisberger, “Augen auf!”, Berner Seminarblätter 6, no. 11 (1910): 459-464, 442.

72 Zinnecker defines childhood and youth as pedagogical moratorium in the sense that, as in other kinds of moratoria, they are released from certain social duties, moral responsibilities and excluded from certain action fields. Pedagogical moratoria are characterised by a generational relationship in which adults take over the responsibility ad interim. Jürgen Zinnecker, "Kindheit und Jugend als pädagogische Moratorien. Zur Zivilisationsgeschichte der jüngeren Generation im 20. Jahrhundert”, in Bildungsprozesse und Erziehungsverhältnisse im 20. Jahrhundert, ed. Dietrich Benner and Heinz-Elmar Tenorth (Weinheim: Beltz 2000), 36-68.
} 
children should be protected from erroneous views about aesthetic values (local instead of foreign manufacture). ${ }^{73}$

While progressive pedagogues proposed child centred education and founded private schools to realise and demonstrate new educational ideas, architects and heritage protection activists reacting against industrialization and massive urbanization proposed an aesthetic reform that should start by transforming the appearance of state school buildings to fit into the given, historically developed, architectural environment. In Switzerland, the Swiss Heritage Protection Association successfully lobbied to implement its values in building legislation. The ideal of the association claimed that the schoolhouse should be embedded in the natural and architectonic environment and not contrast it. Thus, both small and large or monumental, so called school palaces, could be possible. ${ }^{74}$ Alternatives to prevent urbanization not only in its literal sense but also understood as society's mental disposition were proposed as rural idyll. ${ }^{75}$ In Switzerland, although demands for establishing school building regulations and prototype plans initiated in rural areas and peripheries of the Canton of Zurich at the beginning of the nineteenth century, ${ }^{76} \mathrm{school}$ building reform became primarily an urban phenomenon with impact from the centre to the periphery.

Teacher Lina Gubler in Zurich reflected in 1929 on the school building from an urban perspective. Based on her experience in a monumental, centrally placed school building in Zurich City, she plead for decentralised school buildings and spatial separation of the different school levels. ${ }^{77}$ The way to school along congested streets exposed the children to rapidly changing impressions and noise overloading the children's eyes, ears, nerves and psyche so that they lacked concentration in class. According to Gubler, children threatened each other because the elder overran the younger. ${ }^{78}$ This case blurs the material limits of the schoolhouse

\footnotetext{
73 Helfenberger, Das Schulhaus, 191-204.

74 Helfenberger, Das Schulhaus, 196-201.

75 Helfenberger, Das Schulhaus, 207-220.

76 Helfenberger, Das Schulhaus, 61-84.

77 Lina Gubler, "Forderungen an den neuzeitlichen Schulhausbau", Schweizerische Lehrerzeitung 74 (1929): 163-165.

78 Gubler, "Forderungen an den neuzeitlichen Schulhausbau", 163.
} 
to permit schooling practices that the teacher's do not consider lying within their duties. Gubler experienced this bodily as "stressed nerves" because teachers had to spend much time consoling and bandaging children. ${ }^{79}$ Thus, the problematic of the materiality of schooling touched the teachers' professional discourse and jurisdiction in a way that allowed Gubler to trespass them with complaints or proposals relevant of the medical or architecture professions. Gubler's demands are not surprising. Architecture and urban planning had become linked to strategies of social control and reform through moral education since 1900. ${ }^{80}$ She expected society to rethink the organisation of schooling.

Three years later, a working group consisting in $\mathrm{ETH}^{81}$ hygiene professor Wilhelm von Gonzenbach (1880-1955), architect and professor at the ETH Werner M. Moser (1896-1970) and director of the teacher training institute in Küsnacht (Zurich) Willi Schohaus (1897-1981) established a twofold diagnosis: school children were threatened by eight years compulsory schooling and Swiss communities, evidently referring to the school building competition in Altstetten, risked to build new schoolhouses in old, backward manner. Their arguments correspond to the typical progressive education vocabulary. And they extrapolated eight schooling years to ten thousand hours within school buildings to illustrate the dimension of children's risk ${ }^{82}$ evoking progressive education imaginaries of school as a place of torture and the child as a martyr. The organisation of schooling seemed to be of secondary importance.

Teacher trainer Schohaus contrasted his childhood schoolhouse, a small building with mice that allowed for familiarity with the building and amusement with the mice, with school palaces assuming that children could only get lost and feel like strangers in their daily school

\footnotetext{
79 Gubler, "Forderungen an den neuzeitlichen Schulhausbau".

80 Martin Viehhauser, Reformierung des Menschen durch Stadtraumgestaltung. Eine Studie zur moralerzieherischen Strategie in Städtebau und Architektur um 1900 (Weilerswist: Velbrück Wissenschaft, 2016).

81 The Eidgenössische Technische Hochschule (ETH) was founded in 1855 as Switzerland's polytechnical university. It is since then not only an internationally renowned institution of higher education, but also intimately linked with Switzerland's industry and a symbol of innovation and modernity. David Gugerli, Patrick Kupper, and Daniel Speich, Transforming the Future: ETH Zurich and the Construction of Modern Switzerland 1855-2005 (Zürich: Chronos-Verlag, 2010).

82 Wilhelm von Gonzenbach, Werner M. Moser, and Willi Schohaus, eds. Das Kind und sein Schulhaus. Ein Beitrag zur Reform des Schulhausbaues (Zürich: Schweizer-Spiegel-Verlag, 1933).
} 
environment if they had to attend school in such a large and luxurious school building. ${ }^{83}$ Schohaus' remembrance evokes Pestalozzi's metaphor of the living room as educational space. Gonzenbach, Moser and Schohaus broke with the nineteenth century as an overcome era that understood childhood and youth accordingly as a mere transition towards adulthood without intrinsic value. ${ }^{84}$

The 1950s were evidently marked by the experience of World War II. Architect Alfred Roth (1903-1998) sustained that youth was morally and spiritually endangered and required extremely careful education and a healthy environment. ${ }^{85}$ Urbanisation continued to be considered a threat manifested in increasing town traffic that threatened school children on their way to school. ${ }^{86}$ The challenge of town-planning was evidently acute in large cities, as Roth's illustrations in his book demonstrate: overcrowded urbanisations, extremely busy streets and children playing in backyards implying that there are no playgrounds available due to "unhealthy town development". ${ }^{87}$ However, Roth's examples refer to selected cases in the United States or other countries with large cities that become generalised as a worldwide status quo. By doing so, Roth also recurred to a common pattern in reform discourses, a selective, undifferentiated and ideologically decontextualised critique. ${ }^{88}$ Such examples are especially incompatible with the Swiss case.

To add legitimacy to his architectural programme, Roth recurred to a typical reform strategy, the construction of traditions recurring to the social authority of prestigious pedagogues. By referring to Pestalozzi as "the Swiss pioneer of modern education" and by claiming that he "set forth some still valid principles of school design which also bear on the distribution of schools", ${ }^{89}$ Roth also highlighted Switzerland as an educational pioneer nation in general. This is also consistent with the

\footnotetext{
83 Gonzenbach et al., Das Kind, 70.

84 Gonzenbach et al., Das Kind, 76-77.

85 Roth, The new school, 26.

86 Roth, The new school, 9.

87 Roth, The new school, 10.

88 Oelkers, "Reformpädagogik: Aktualität und Historie", 25.

89 Roth, The new school, 10.
} 
construction of Swiss school buildings as most modern and progressive since Varrentrapp and especially since the onset of the World Exhibitions. ${ }^{90}$ Those principles of school design are limited to school education as the extension of parental education. ${ }^{91}$ Pestalozzi did not discuss school building design at all. But school building architects before Roth also affirmed that the school building should playback the atmosphere of the "Wohnstube". It had become clear to him that recurring only to traditions of his own profession could not be enough. As for the motto of modern architecture "form follows function" by Louis Sullivan from the early 1880 s meaning that "construction is not only an integral part of the aesthetic appearance of a building but of its inner moral also", 92 it should be noted that it had also been requested by hygienists and health professionals such as Varrentrapp before modern architects popularised it.

Despite acknowledging hard overall conditions during the nineteenth century, Roth neglected against all empirical facts and programmatic discourses ${ }^{93}$ the actual performance of its school institutions in education and also in school building. The onset of modern schooling as state affair of public importance and the consequent search for adequate school architecture, although identified at the beginning of the nineteenth century, did not, according to Roth, lead to meaningful school building solutions because

During the second half of the 19th century, the decline of architectural conception and creative thought was rapidly approaching the lowest possible level characteristic of a deeply uprooted and contradictory epoch. The architects of that period held on to certain vague traditions which, in no way, correspond to modern times. ${ }^{94}$

Thus, he could state that it was not until the architecture profession took over the authority over school building from the state that these could become modernised. It is against this discursive background that

\footnotetext{
90 Helfenberger, "Climate as artefact".

91 Roth, The new school, 12.

92 Roth, The new school, 30.

93 Helfenberger, Das Schulhaus.

94 Roth, The new school, 24.
} 
Roth could legitimate a total break with the nineteenth century accusing it of (exclusively) constructing "out-sized buildings; unfunctional and undifferentiated space organisation; unfunctional and non-creative design" ${ }^{95}$

To him, nineteenth century society was "not aware of public education as a social obligation" leading to chaotic urban planning and the understanding of school buildings as "isolated, formal problem with the ultimate aim of public demonstration" ignoring distances between school buildings and children's homes, "quite, healthy and pleasant environments" and the local anchoring of the school. ${ }^{96}$ The charge against using the school building for "public demonstration" of the state had been qualified as "monumentalism" by Gonzenbach, Moser and Schohaus who even proposed that maximum schoolhouse dimensions should be implemented by official regulations to prevent the construction of "a house that, in its quest for monumentality, expresses only the will to represent". ${ }^{97}$ Roth attributed that non-awareness of the importance of public education to materialist and utilitarian mentalities and practices that exposed town-planning to private speculation. ${ }^{98}$

By such selective historical reception or lack of historical conscience, old knowledge and practices could be presented as new and modern solutions: that the number of rooms should be planned and that the need for special rooms for specific subjects and activities needs to be taken into account to allow for a successful organisation of schooling are some examples.

\section{THE SCHOOLHOUSE AS CO-EDUCATOR AND THE NATURALIZATION OF HISTORICAL BUILDING DESIGNS}

Georg Varrentrapp attributed educational value to the schoolhouse. For him, school and school buildings had to contribute to "children's intellectual, moral and physical development". ${ }^{99}$ Varrentrapp reacted to

\footnotetext{
95 Roth, The new school, 26.

96 Roth, The new school, 8-14.

97 Gonzenbach, et al., Das Kind, 6.

98 Roth, The new school, 8.

99 Varrentrapp, Der heutige Stand.
} 
industrialization and subsequent social problems engaging in professional health discourses and hygiene activism. He understood the school building not just as a container of schooling, but as a kind of textbook to promote children's health, education and instruction by means of adequate construction and housekeeping. Such a school building would reflect the task society assigns to school -development of the child's intellect, morals and body- and by transmitting this message, it would also educate society. ${ }^{100}$ At the same time, school inspectors in rural Switzerland, where school buildings resembled farmhouses, emphasised more on school rooms as educational instruments serving teachers rather than the building as a whole. And it is the inner setting they associated with old and new education and the educationalization of the school building: as children lacked cleanliness, order, light and good material conditions at home, a correctly built and maintained schoolhouse was expected to help teachers transmit values of hygiene and tidiness to children. ${ }^{101}$

Early twentieth century, heritage protection activists aimed at a "pedagogic architecture". The school building became understood as identity-creating instrument by means of harmonic town-planning and aesthetics. It would represent the character of the people, the city or village, homeland. The child should feel at home in school thus, the schoolhouse should not be monumental. Aesthetic quality of the schoolhouse would educate the child and his or her good taste because arts were expected to raise the sense of ideals. Aesthetic experience was supposed to have a lasting effect on children's soul and their concept of school because of their 'natural' receptiveness for beauty. Thus, a beautiful, clearly formed but unpretentious school building would correspond to school's inner and real purpose. Such a beautiful school building would be a "secret" or "silent" co-educator ${ }^{102}$ for its own sake transmitting beauty as lasting good for life, because it reflects its natural truth and beauty. In this way,

\footnotetext{
100 Helfenberger, Das Schulhaus.

101 Helfenberger, Das Schulhaus, 135-139.

102 The original term in German is "geheimer Miterzieher". Two translations could be possible: "hidden" drawing on Snyder's concept of the hidden curriculum or "secret". I opted to translate it as "secret" because the historical actors use it in a deliberate and strategical way. Thus, the negative effects they attribute to the "school caserns" would apply to a "hidden" co-educator because they assume that architects, pedagogues and authorities who built them, did not reflect on the consequences of such buildings. Benson R. Snyder, The Hidden Curriculum (New York: A.A. Knopf, 1971).
} 
illumination became friendliness, and favouring local materials and workers in face of presumed foreign influences that could harm the local manufacture market became modesty, honesty and nature bondedness. ${ }^{103}$ These were values that should be transmitted by the aesthetics of the school building. Together with actors of the national heritage protection movement, professionalised architects engaged pedagogically and significantly contributed to the construction of the school building as "secret co-educator". ${ }^{104}$

In the 1930s, the school building's spirit was expected to contribute to impress young souls. Seemingly analogous to the child's soul, the school building should be friendly, clear, modest, honest and close to nature, being them pedagogical criteria that should dominate over any other requirements. ${ }^{105}$

Gonzenbach, Moser and Schohaus proposed an architectonic and urbanistic solution to create that protected space that corresponds materially to youth as pedagogical moratorium. They claimed for decentralised schoolhouses placed in the centres of residential areas and green areas, short and danger free ways to school that are pleasant, small classes and outdoor space. This space of education becomes hygienically and socially functional. And it is also psychological as they assumed that schooling represents a shock for school children as they change from "small social groups" into a "whole school population". 106

The apparently natural architectural solution to this particular relation between form and function is the pavilion and low-rise construction. ${ }^{107}$ Also, Moser, the architect, naturalised the historically contingent architectural aesthetic values affirming the need of collaboration between city administration and social planners. As for the case of Zurich during the first half of the twentieth century, it is known that among

\footnotetext{
103 Helfenberger, Das Schulhaus, 221-236; Helfenberger, "Climate as artefact".

104 Helfenberger. Das Schulhaus.

105 Gonzenbach et al., Das Kind, 5-6.

106 Gonzenbach et al., Das Kind, 9.

107 Gonzenbach et al., Das Kind, 17.
} 
those social planners, architects collaborated with own pedagogical and social reform ambitions through architecture. ${ }^{108}$

Recalling on experiences in Switzerland and abroad, Gonzenbach affirmed that "the child profits the most also in spiritual and that is pedagogical terms" from pavilion and low-rise constructions. However, to demonstrate this with arguments, he spoke hygienically and medically (e. g. the risk of infections). ${ }^{109}$ By doing so, Gonzenbach departed from a specific definition of child's nature to naturalise a specific architectural solution for school buildings. He called the fact of spending time indoors "time of domestication" that would not go along with natural adaptation. He stated that children -apparently it does not apply to adultsare naturally born connected to nature. Thus, school should respect and reflect the child's "natural law being," that is, school should be as much as possible open-air. ${ }^{110}$

Alfred Roth defined school building as "the most urgent and fascinating tasks of contemporary architecture" that had to be seen in the "full context of education, life, and the creative powers". ${ }^{111}$ School building became educationalized in two senses: to reinforce school's societal, cultural and artistic inclusion by means of targeted town-planning and to educate for peace in a preventive sense by providing "progressive education in an adequate physical environment". ${ }^{112} \mathrm{He}$ published his book "Das neue Schulhaus" in three languages, "a fact which at the same time pays tribute to the important educational ideal of international understanding, which must take its root in the schools". ${ }^{113}$ Thus, school building critique became a socially preventive and constructive dimension rather than blaming the school building as source of danger itself, as it was the case in the nineteenth century.

Roth, as architect, became an advocate of progressive education and educator of architects, building professions, town-planners, sociologists,

\footnotetext{
108 Viehhauser, Reformierung des Menschen.

109 Gonzenbach et al., Das Kind, 9.

110 Gonzenbach et al., Das Kind, 9.

111 Gonzenbach et al., Das Kind, 9.

112 Gonzenbach et al., Das Kind, 9.

113 Roth, The new school, 6.
} 
public authorities and teachers. He emphasised the importance of "as close a connection as possible, both practically and emotionally [...] between the school and the home" expanding the horizon to town-planning. ${ }^{114}$

Thus, the schoolhouse became educationalized for several purposes: to promote progressive education in this case; but, also to emphasise the role of town-planning for the aesthetic and moral education of the young. For communal school planning, careful analysis of the locality, neighbouring quarters and a town as a whole should be realised to prevent health, education and landscape destruction. Roth offered a simple solution: to differentiate both from the angle of the child and that of education relying on (modern) pedagogy which is in reality psychology, more specifically Freud, Adler and Jung. Because psychology provides for constant evolution of knowledge about the child, schoolhouses need to be flexible and permit internal and external alterations according to new pedagogic needs. Roth diagnosed that "a school built at great cost to last for many generations will age much sooner, and become more quickly inadequate than a lightly built adaptable one". ${ }^{115}$ Paradoxically, nineteenth century school buildings have proved to be very flexible and functional. Teachers and students have proven creativity to appropriate school space.

All these views and their proposals to solve challenges have something in common: all use the child as argument. In the mid nineteenth century, children's health is considered at risk because of school attendance. Thus, school becomes something like a better home that should protect them. At the beginning of the twentieth century, it is the child's soul that is endangered by alienation. Children are conceived as naturally happy, curious and creative. ${ }^{116}$ Thus, school architecture has to be artistic to preserve this nature. Discursively, progressive educators reduced the impact of the school building to physical and psychological effects. ${ }^{117}$ School's task to further intellectual development becomes a subordinate

\footnotetext{
114 Roth, The new school, 12.

115 Roth, The new school, 34.

116 Oelkers, "Reformpädagogik: Aktualität und Historie".

117 Gonzenbach et al., Das Kind.
} 
role and is attributed to adults. Ellen Key's book The Century of the Child ${ }^{118}$ is representative of a community of thought that claimed to be progressive by distinguishing between the "right" and the "wrong" side: being the advocate of the child was progressive and right, other educational perspectives could be labelled as backward. ${ }^{119}$ By naturalising certain aesthetic and design qualities of the school building as correspondent to the child's nature, monumental school architecture could be labelled as representative of a "school spirit from an overcome era". ${ }^{120}$

The self-positioning of architects as the child's advocates adopting jargon and strategies of progressive educators began in the 1910s by publicity ${ }^{121}$ and within school building competitions. Shortly after the inauguration of the schoolhouse in Neuhausen in 1914, the report on the building expresses regret that the architects could not enforce levelling the terrain to design the main playground. Thus, the "natural consequence is now that the children prefer the much more interesting northern parts of the playground". ${ }^{122}$

\section{EDUCATIONALIZING SCHOOL ARCHITECTURE - THREE PROFESSIONS AND ONE DISCOURSE}

School building critique, despite all the aesthetic variability, reveals structural continuity: contemporary schoolhouses correspond to representation needs rather than to the school's function. And the precedent generations are to blame because they did not understand the real function of schooling. The controversy lied again and again in the changing aesthetic values and the changing imaginaries of childhood. Thus, new architectural values seem to have to be defended against earlier ones, mostly those from the immediately precedent generation. When it comes to building (elementary) schoolhouses, the discussion differs from that

\footnotetext{
118 Ellen Key, The century of the child (New York, London: The Knickerbocker Press, G.P. Putnam, 1909).

119 Oelkers, "Reformpädagogik: Aktualität und Historie", 38-39.

120 Gonzenbach et al., Das Kind, 6.

121 Helfenberger, Das Schulhaus, 257-263.

122 SIA, "Neues Schulhaus in Neuhausen", Schweizerische Bauzeitung 63/64 (1914): 49.
} 
lead by other kinds of public buildings such as hospitals, city council halls or museums: A museum does not seem to have to meet artistic needs, or a hospital medical needs, or a city council hall political needs. But a schoolhouse has to meet educational requirements. Education and the child became sublimated, because childhood was understood as the future of society and education should guarantee a better future. It seems thus paradox that the school building becomes educationalized as a co-educator.

The idea of the co-educator persisted during our research period being publicly contested by three professions: pedagogues, doctors and architects. Since Varrentrapp, an appealing aesthetic should promote the child's acceptance and well-being in school so that it keeps a positive remembrance and thus a positive attitude towards school. In the time of the social question, children should feel safe and secure because the schoolhouse had to provide for a clean atmosphere they lacked at home. Around 1900 they should feel at home in school because the building would resemble home as. It should be seen as continuation and extension of parental education. The classroom and the schoolhouse should afford the same sense of natural security and intimacy with which the child is familiar at home. Then, in the 1950s this feeling should develop thanks to the resized infrastructure in accordance with the child's body dimensions.

Despite this child-centeredness, the schoolhouse as material manifestation of schooling becomes a curriculum actor: it becomes an active collaborator to solve nutrition deficits when placed in residential zones allowing children to "at least one reasonable meal per day" offered by the school. ${ }^{123}$ It also collaborates to fulfil other tasks attributed to school such as the "mission, to bring youth in touch with contemporary art," 124 or to provide youth with "aesthetic and social views and the ability to religious experience and aesthetic perception". ${ }^{125}$ By adopting a simple and functional appearance instead of being "representative", it would better contribute to citizenship education or education to work. ${ }^{126}$

\footnotetext{
${ }_{123}$ Gonzenbach et al., Das Kind, 10.

124 Gonzenbach et al., Das Kind, 11.

125 Gonzenbach et al., Das Kind, 74.

126 Gonzenbach et al., Das Kind, 10-14.
} 
Finally, school was conceived as natural carrier of the social education task meaning that children grow up into capable community members that enhance community life and feeling, into developers of a peaceful and constructive future of all peoples.127 All elements of the schoolhouse, from the façade to the school desks and door handles should be designed with these educational added values in mind. Following reform education patterns of using practice and examples as proof, Roth uses the image of a British schoolboy that is supposed to participate at town-planning investigations about pollution, and thus develops community spirit. ${ }^{128}$

By the mid twentieth century, architects had engaged in standard reference publications and specific exhibitions, ${ }^{129}$ thus definitely empowered themselves with sovereignty of definition in the field of school building and acted as pedagogic actors responding to pedagogic discourses of child centred education. By doing so, they also contributed to the educationalization of architecture and public space. As in the German case, healthy, beautiful and progressive school materialised in the new school architecture. ${ }^{130}$ Between 1880s and 1950, the power of definition over the building plan and competition procedures, competition consequences (decisions and attributions), submissions for construction works, competition exhibitions, and last but not least over the concept of the schoolhouse as public building, were contested. The increasing number of academic architects graduated from the ETH lead to an engaged lobbying from the SIA to popularise their professional norms and standards also in the field of school building. And further, they acquired more and more power of definition in general. During the nineteenth century, construction works were submitted for competition

\footnotetext{
127 Gonzenbach et al., Das Kind, 11

128 Roth, The new school, 60.

129 Henry Baudin, Les constructions scolaires en Suisse: écoles enfantines, primaires, secondaires, salles de gymnastique, mobilier, hygiène, décoration, etc., etc. (Genève: Éditions d'Art et d'Architecture, 1907); Henry Baudin, Les nouvelles constructions scolaires en Suisse: écoles primaires, secondaires, salles de gymnastique, hygiène, décoration, etc. (Genève : Ed. d'Art et d'Architecture Kundig H Gaulon, 1917); Kunstgewerbemuseum Zürich, Ausstellung der neue Schulbau: 10. April-14. Mai 1932; Wegleitungen des Kunstgewerbemuseums der Stadt Zürich. Zürich: [Kunstgewerbemuseum], 1932; Roth. The new school.
}

130 Heidemarie Kemnitz, "Denkmuster und Formensprache pädagogischer Architekturen im ersten Drittel des 20. Jahrhunderts" in Das Jahrhundert der Schulreformen. Internationale und nationale Perspektiven, 1900-1950, ed. Claudia Crotti and Fritz Osterwalder (Bern, Stuttgart, Wien: Haupt, 2008), 251-281. 
to receive different offers and budgets. It was mostly the building owner who took care of tender and decisions. More and more though, constructing architects organised these inquiries and choices themselves. ${ }^{131}$

The architecture profession became an important player in school building within the complex governance network of Swiss federalism. Even though school building regulations or guidelines are cantonal, Swiss communities have large autonomy in school administration. Members of local school authorities are considered non-professionals in the sense that they are elected by the people and do not necessarily exercise any kind of school related profession, including the construction and architecture fields. Apart from the fact that school building is an interdisciplinary task, it is at the core of public interest and thus a large number of participants demands to be heard. Therefore, it is no coincidence that the field of school building and related architecture competitions became contested at the beginning of the twentieth century.

It is a common complaint that architects, and pedagogues do not sufficiently collaborate. At the same time, modern architects and progressive educators that were active in school building discourses as a group claim for themselves to be innovative and indeed find a common language based on juxtaposed educational reform language and historically contingent aesthetic values. However, collaboration activities date from the nineteenth century. At the time of the Vienna International Exhibition in 1873, architect August Krumholz and pedagogue Erasmus Schwab worked together to present a life-size model of the ideal Austrian schoolhouse. The discourse at the time emphasised the need for collaboration between the different involved experts and school authorities. Such collaborations should result in good school building practice. Regardless the fact that there are indeed not many collaborations resulting in publications, a trans-professional circulation of knowledge took very well place in the last third of the nineteenth century. Doctors, architects and pedagogues repeated each other and adopted each other's arguments into the own professional understanding. In the 1930s and again in the 1950s, times of construction booms, jointed architects, pedagogues and doctors felt that evils from the past were still menacing school architecture and had to be prevented. ${ }^{132}$

\footnotetext{
131 e.g. Karl Moser, “Schulhausneubau in Wohlen”, Schweizerische Bauzeitung 29/30 (1897): 1.

132 Gonzenbach et al., Das Kind, 6.
} 
The construction of the schoolhouse as co-educator, school building architecture competitions, public and professional discourses contributed to educationalize the schoolhouse attributing to its design not only aesthetic value but also relating it to educational solutions to society's social problems or challenges. A paradigmatic example of a school building claiming to be democratic architecture is Hans Scharouns girl's high school in Lünen Germany. 133

The schoolhouse as co-educator in the name of the child has become a common denominator that seems to unify three professions and a large diversity of viewpoints. But it also assures the continuity of critique and the never-ending search for the ideal school building. The medical profession was successful in school regulation lobbying to implement their educational ideal and to establish their position. The architecture profession could establish competition norms and the social acceptance of school building competitions. The teaching profession stands in between and more historical research on their appropriation of school building is needed to contrast educational reform programs. In Switzerland, every school building project requires again and again new negotiations between the participants resulting in unique school buildings -each of them a prototype awaiting development. Three years after Roth's publication, a schoolhouse exhibition took place in Zurich motivated by the increasing need for new school buildings. Again, a trans-professional collaboration, this exhibition permitted the definitive popularization of the educationalized schoolhouse. Calls for tender and competition documentation can be an important historical source for further research in history of education.

\section{Note on the author}

Marianne Helfenberger (San José, Costa Rica, 1970) holds a PhD from the University of Bern, Switzerland, in History of Education. Research focuses are: School and educational history in Switzerland, school building and architecture, democracy and schools in Latin America, professionalization of educational professions. She is scientific collaborator at

133 Heidemarie Kemnitz, "Schulbau jenseits der Norm: Hans Scharouns Mädchengymnasium in Lünen”, Paedagogica Historica 45, no. 4/5 (2007): 605-625. 
Swiss Distance University, Überlandstrasse 12, 3900 Brig, Switzerland. helfenbergersanz@gmail.com, marianne.helfenberger@fernuni.ch.

\section{REFERENCES}

Abbott, Andrew D. The System of Professions : An Essay on the Division of Expert Labor [Reprint]. Chicago: The University of Chicago Press, 2009.

Allemann-Ghionda, Cristina. "Dewey in Postwar-Italy: The Case of Re-Education" in Studies in Philosophy and Education 19, no. 1 (2000): 53-67.

Bakker, Nelleke and Fedor de Beer, "The dangers of schooling: the introduction of school medical inspection in the Netherlands (c.1900)". History of Education 38, no. 4 (2009): 505-524).

Braun, Rudolf. “Arbeits- und Lebensverhältnisse des Fabrikwesens als soziales Problem”. In Sozialer und kultureller Wandel in einem ländlichen Industriegebiet im 19. und 20. Jahrhundert, edited by Rudolf Braun, 109-185. Zürich: Chronos, 1999.

Bridges, David. "Educationalization: on the Appropriateness of Asking Educational Institutions to Solve Social and Economic Problems". Educational Theory 58, no. 4 (2008): 461-474.

Bruno-Jofré, Rosa, ed. Educationalization and its Complexities : Religion, Politics, and Technology. Toronto: University of Toronto Press, 2019.

Caruso, Marcelo et al. Zirkulation und Transformation: Pädagogische Grenzüberschreitungen in historischer Perspektive. Köln: Böhlau-Verlag GmbH, 2013.

Conrad, Peter. The medicalization of society. On the transformation of human conditions into treatable disorders. Baltimore: John Hopkins University Press, 2007.

Depaepe, Marc and Paul Smeyers, eds. Educational research: the educationalization of social problems. Dordrecht: Springer, 2008.

Depaepe, Marc and Smeyers Paul, "Educationalization as an ongoing Modernization Process”. Educational Theory 58, no. 4 (2008): 379-389

Depaepe, Marc. De pedagogisering achterna: aanzet tot een genealogie van de pedagogische mentaliteit in de voorbije 250 jaar. Leuven: Acco, 1998.

Espagne, Michel. L'histoire de l'art comme transfert culturel: l'itinéraire d'Anton Springer. Paris: Belin, 2009.

Fontaine, Alexandre. Aux heures suisses de l'école républicaine. Un siècle de transferts culturels et de déclinaisons pédagogiques dans l'espace franco-suisse. Paris: Demopolis, 2015.

Foucault, Michel. Die Geburt der Klinik: eine Archäologie des ärztlichen Blicks. Frankfurt am Main: Fischer Taschenbuch, 2016. 
Giuliani, Frédérique, ed. L'école et la question sociale: les recompositions actuelles de l'action éducative. Genève: Section des sciences de l'éducation, Université de Genève, 2018.

Gonon, Phillip. Das internationale Argument in der Bildungsreform : Die Rolle internationaler Bezüge in den bildungspolitischen Debatten zur Schweizerischen Berufsbildung und zur englischen Reform der Sekundarstufe II. Bern: Peter Lang, 1998.

Gugerli, David, Patrick Kupper and Daniel Speich, Transforming the Future: ETH Zurich and the Construction of Modern Switzerland 1855-2005. Zürich: Chronos-Verlag, 2010.

Helfenberger, Marianne and Karin Manz. "Der Auf- und Ausbau der "modernen” Volksschule". In Schweizer Bildungsgeschichte - Systementwicklung im 19. Und 20. Jahrhundert, edited by Ingrid Brühwiler et al., forth. Zürich: Chronos, 2021.

Helfenberger, Marianne. Das Schulhaus als geheimer Miterzieher. Normative Debatten in der Schweiz von 1830 bis 1930. Bern: Haupt, 2013.

Helfenberger, Marianne. "Climate as artefact between 1830 and 1930: A transnational construction of the Swiss school building". History of Education 47, no. 5 (2018): 237-264.

Helfenberger, Marianne. "Schulhausbau in Zürich von 1860 bis 1920 - zwischen Expertenherrschaft und öffentlicher Kontrolle”. In Gemeinden in der Schul-Governance der Schweiz. Steuerungskultur im Umbruch, edited by Judith Hangartner and Markus Heinzer, 221-248. Wiesbaden: Springer VS, 2016.

Hofmann, Michèle. "Ein schwacher Geist in einem schwachen Körper? Popularisierung medizinischen Wissens über geistige Schwäche im ausgehenden 19. und beginnenden 20. Jahrhundert in der Schweiz”. Spurensuche. Zeitschrift für Geschichte der Erwachsenenbildung und Wissenschaftspopularisierung, 27 (Die Bildung des Körpers - Medizin, Gesundheit und Bewegung in der Volks- und Erwachsenenbildung des 19. und 20. Jahrhunderts), (2018): 4-13.

Hofmann, Michèle. "Schule und die Pädagogisierung gesellschaftlicher Probleme”. In Schweizer Bildungsgeschichte - Systementwicklung im 19. und 20. Jahrhundert, edited by Ingrid Brühwiler et al., forth. Zürich: Chronos, 2021.

Hofmann, Michèle. Gesundheitswissen in der Schule. Schulhygiene in der deutschsprachigen Schweiz im 19. und 20. Jahrhundert. Bielefeld: transcript, 2016.

Imlig, Flavian, Lukas Lehmann, and Karin Manz, eds. Schule und Reform: Veränderungsabsichten, Wandel und Folgeprobleme. Wiesbaden: Springer Vieweg, 2018. 
Kemnitz, Heidemarie. "Denkmuster und Formensprache pädagogischer Architekturen im ersten Drittel des 20. Jahrhunderts”. In Das Jahrhundert der Schulreformen. Internationale und nationale Perspektiven, 1900-1950, edited by Claudia Crotti and Fritz Osterwalder, 251-281. Bern, Stuttgart: Haupt, 2008.

Kemnitz, Heidemarie. "Schulbau jenseits der Norm: Hans Scharouns Mädchengymnasium in Lünen”. Paedagogica Historica 45, no. 4/5 (2007): 605625.

Kerbs, Diethart and Jürgen Reulecke. Handbuch der deutschen Reformbewegungen 1880-1933. Wuppertal: Hammer, 1998.

Krabbe, Wolfgang R. Gesellschaftsveränderung durch Lebensreform: Strukturmerkmale einer sozialreformerischen Bewegung im Deutschland der Industrialisierungsperiode. Göttingen: Vandenhoeck and Ruprecht 1974.

Labaree, David, “The Winning Ways of a Losing Strategy. Educationalizing Social Problems in the United States", Educational Theory 58, no. 4 (2008): 447-460.

Latour, Bruno. The Pasteurization of France. Cambridge, Mass.: Harvard University Press, 1993.

Lefebvre, Henri. La Production de l'espace. Société et Urbanisme. Paris: Editions Anthropos, 1974.

Livingstone, David N. "Keeping knowledge in site”. History of Education 39, no. 6 (2010): 779-785.

Loetz, Francisca. Vom Kranken zum Patienten: "Medikalisierung" und medizinische Vergesellschaftung am Beispiel Badens, 1750-1850. Stuttgart: Universität Heidelberg, 1993.

Michalzik, Peter. 1900: Vegetarier, Künstler und Visionäre suchen nach dem neuen Paradies. Köln: DuMont, 2018.

Oberhänsli, This. Vom "Eselstall” zum Pavillonschulhaus: Volksschulhausbauten anhand ausgewählter Luzerner Beispiele zwischen 1850 und 1950. Luzern: Kommissionsverlag Raeber Bücher AG, 1996.

Oelkers, Jürgen. "Reformpädagogik vor der Reformpädagogik”. Paedagogica Historica 42, no. 1-2 (2006): 15-48.

Oelkers, Jürgen. "Reformpädagogik: Aktualität und Historie”. In Reformpädagogik kontrovers, edited by Wilfried Böhm and Jürgen Oelkers, 23-47. Würzburg: Ergon Verlag, 1999.

Oelkers, Jürgen. Reformpädagogik: Eine kritische Dogmengeschichte. Weinheim: Juventa, 1996.

Osterwalder, Fritz. "Das gute Kind - pädagogische Modernität und ihr theologisches Erbe”. In Gut/Böse - ein Januskopf?, edited by Eva Marsal and Regina Speck, 19-41. Bern, Frankfurt a.M.: Lang, 2008.

Osterwalder, Fritz. Pestalozzi - ein pädagogischer Kult: Pestalozzis Wirkungsgeschichte in der Herausbildung der modernen Pädagogik. Weinheim, Basel: Beltz, 1996. 
Peter, Claudia and Carolin Neubert. "Medikalisierung Sozialer Prozesse". In Soziologie von Gesundheit und Krankheit, edited by Matthias Richter and Klaus Hurrelmann, 273-285. Wiesbaden: Springer Fachmedien Wiesbaden, 2016.

Rindlisbacher, Stefan. Die Schweizer Lebensreformbewegung: Anleitungen für ein "besseres Leben". In Lebe besser! : auf der Suche nach dem idealen Leben, edited by Eva Locher, 17-29. Bern: Eigenart, 2020.

Roediger, Emil. "Varrentrapp, Georg”, in Allgemeine Deutsche Biographie 39 [1895], 500-502 [online version]. http://www.deutsche-biographie.del sfz83539.html, 500-502 (retrieved January 26, 2021).

Rose, Anton H. Die Lösung der sozialen Frage durch die Schule im neuen Deutschland. Leipzig: Verlag von Wilh. Grunow, 1919.

Schmid, Marcel, ed. Die Literatur der Lebensreform: Kulturkritik und Aufbruchstimmung um 1900. Bielefeld, Germany: transcript, 2016.

Schneeberger, Elisabeth. Schulhäuser für Stadt und Land. Der Volksschulhausbau im Kanton Bern am Ende des 19. Jahrhunderts. Bern: Historischer Verlag des Kantons Bern, 2005.

Schultheis, Klaudia. "Reformpädagogik - eine Pädagogik vom Erwachsenen aus?”. In Reformpädagogik konstrovers, edited by Winfried Böhm and Jürgen Oelkers, 89-104. Würzburg: Ergon, 1995.

Snyder, Benson R. The Hidden Curriculum. New York: A.A. Knopf, 1971.

Tröhler, Daniel. Pestalozzi and the Educationalization of the World. New York, N.Y.: Palgrave Macmillan, 2013.

Viehhauser, Martin. Reformierung des Menschen durch Stadtraumgestaltung. Eine Studie zur moralerzieherischen Strategie in Städtebau und Architektur um 1900. Weilerswist: Velbrück Wissenschaft, 2016.

Zinnecker, Jürgen. "Kindheit und Jugend als pädagogische Moratorien. Zur Zivilisationsgeschichte der jüngeren Generation im 20. Jahrhundert”, in Bildungsprozesse und Erziehungsverhältnisse im 20. Jahrhundert, edited by Dietrich Benner and Hein-Elmar Tenorth, 36-68. Weinheim: Beltz 2000.

Zola, Irving K. "Medicine as an institution of social control". In The sociology of health and illness. Critical perspectives, edited by Peter Conrad, 404-414. New York: Worth, 1972.

Zymek, Bernd. Das Ausland als Argument in der pädagogischen Reformdiskussion : Schulpolitische Selbstrechtfertigung, Auslandspropaganda, internationale Verständigung und Ansätze zu einer Vergleichenden Erziehungswissenschaft in der Internationalen Berichterstattung. Kastellaun: Aloys Henn, 1975. 